\title{
Indigeneous Streptomyces spp. isolated from Cyperus rotundus rhizosphere indicate high mercuric reductase activity as a potential bioremediation agent
}

\author{
HANUM MUKTI RAHAYU ${ }^{1}$, WAHYU ARISTYANING PUTRI ${ }^{2}$, ANIS USWATUN KHASANAH ${ }^{3}$, \\ LANGKAH SEMBIRING ${ }^{4}$, YEKTI ASIH PURWESTRI ${ }^{5, \varphi}$ \\ ${ }^{1}$ Program of Biology Education, Faculty of Teacher Training and Education, Universitas Muhammadiyah Pontianak. Jl. Ahmad Yani No. 111, Pontianak \\ 78124, West Kalimantan, Indonesia \\ ${ }^{2}$ Biotechnology Laboratory, Department of Tropical Biology, Faculty of Biology, Universitas Gadjah Mada. Jl. Teknika Selatan, Sekip Utara, Sleman 55281, \\ Yogyakarta, Indonesia \\ ${ }^{3}$ Biology Laboratory, Program of Biology, Faculty of Science, UIN Sultan Maulana Hasanuddin Banten. Jl. Jendral Sudirman No. 30, Kota Serang \\ 42118, Banten, Indonesia \\ ${ }^{4}$ Microbiology Laboratory, Department of Tropical Biology, Faculty of Biology, Universitas Gadjah Mada. Jl. Teknika Selatan, Sekip Utara, Sleman \\ 55281, Yogyakarta, Indonesia \\ ${ }^{5}$ Biochemistry Laboratory, Department of Tropical Biology, Faculty of Biology, Universitas Gadjah Mada. Jl. Teknika Selatan, Sekip Utara, Sleman \\ 55281, Yogyakarta, Indonesia. Tel.: +62-274-580839, ’email: yekti@ugm.ac.id
}

Manuscript received: 15 January 2021. Revision accepted: 26 February 2021

\begin{abstract}
Rahayu HM, Putri WA, Khasanah AU, Sembiring L, Purwestri YA. 2021. Indigenous Streptomyces spp. isolated from Cyperus rotundus rhizosphere indicate high mercuric reductase activity as a potential bioremediation agent. Biodiversitas 22: 1519-1526. The purification and characterization of mercuric reductase of four indigenous Streptomyces spp. from Cyperus rotundus L. rhizosphere in mercury-contaminated area have been investigated. Cell-free extract was obtained by disrupting cells using sea sand at $4{ }^{\circ} \mathrm{C}$ followed by centrifugation. Mercuric reductase was purified by ammonium sulfate precipitation, dialysis, and chromatography column (DEAE Sepharose anion column chromatography). The determination of optimum $\mathrm{pH}$ and temperature of mercuric reductase activity was measured based on the number of $\mathrm{NADPH}_{2}$ oxidized to NADP per mg protein per minute using a spectrophotometer. The molecular weight of mercuric reductase was determined using SDS-PAGE. Result showed that the highest specific activity of mercuric reductase was recorded from Streptomyces spp. BR28. The optimum $\mathrm{pH}$ and temperature of cell-free extract enzyme mercuric reductase were 7.5 and $80^{\circ} \mathrm{C}$, respectively. The enzyme was purified to 431.87 -fold with specific activity $21918.95 \mathrm{U} / \mathrm{mg}$ protein. SDS PAGE showed that the molecular weight of mercuric reductase in Streptomyces spp. BR 28 ranged from $50 \mathrm{kDa}$ to $75 \mathrm{kDa}$. It can be concluded that Streptomyces isolates contain mercuric reductase and have potential as mercury bioremediation agent to overcome mercury contamination in the environment.
\end{abstract}

Keywords: Cyperus rotundus, mercuric reductase, mercury, Streptomyces

\section{INTRODUCTION}

MRB or Mercury resistant bacteria have a broad spectrum of gram-positive and gram-negative bacteria. They have a peculiar mechanism of encounter and eventually convert $\mathrm{Hg}$ from highly toxic to non-toxic form (Dash and Das 2012; Kumari et al. 2020). MRB population is proportional to the scale of $\mathrm{Hg}$ pollution at the site (Dash and Das 2012; Winardi et al. 2019). Many bacteria are found to be resistant to mercury and classified as MRB including Shigella flexneri, Pseudomonas putida, Pseudomonas stutzeri, $P$. fluorescens, $P$. aeruginosa (Fatimawali et Al. 2019; Imron et al. 2019), Firmicutes, Planctomycetes (Fatimawali et al. 2020), Klebsiella pneumoniae, Morganella morganii, Xanthomonas, Achromobacter spp., Sphingobium spp., Acinetobacter calcoaceticus, Serratia marcescens, Mycobacterium marinum, Bacillus spp., Enterobacter, Staphylococcus aureus, Sphingopyxis spp., Psychrobacter spp., Brevibacillus spp., Anoxybacillus spp., Luteimonas spp., and Geobacillus kaustophilus (Mahbub et al. 2017), Brevundimonas spp. (Irawati et al. 2012), Actinomycetes and Streptomycetes (Undabarrena et al. 2017).

Streptomyces spp. is one of MRB which belongs to the genera Actinomycetes. It is aerobic, gram-positive bacteria (Deepika and Kannabiran 2010; Popa and Bahrim 2011), and has G-C content $>50 \%$ (guanine and cytosine) (Rintala 2003). Morphologically, this bacteria is different from other bacteria because it has a hyphae structure that forms the mycelium (Popa and Bahrim 2011) and undergoes morphological changes during its life cycle (Popa and Bahrim 2011). Streptomyces is a group of saprophytic bacteria (Deepika and Kannabiran 2010), most of which can be found in soil habitats (Deepika and Kannabiran 2010; Popa and Bahrim 2011; Madigan et al. 2012) no exception to soils contaminated with mercury.

Streptomyces spp. can be used as a solution to the problem of biological mercury pollution through a detoxification process. Detoxification mainly converts toxic heavy metal ions to non-toxic ions (Madigan et al. 
2012). The mechanism of mercury detoxification by bacteria occurs with various systems, one of which is the reduction of $\mathrm{Hg}^{2+}$ to $\mathrm{Hg}^{0}$ (volatile) using mercury reductase enzyme (Hughes and Poole 1989; Madigan et al. 2012; Kumari et al. 2020) which is produced by merA (Kumari et al. 2020). Bacteria that can reduce $\mathrm{Hg}^{2+}$ to $\mathrm{Hg}^{0}$ are generally mercury-resistant bacteria (Weiss et al. 1977; Gopinath et al. 1989; Huang et al. 2010) and can be used as a bioremediation agent to reduce mercury waste in the environment (Purkan et al. 2017).

Indonesian artisanal and small-scale gold mining activities (ASGM) have been found in the islands of Borneo (Kalimantan), Buru, Sulawesi, Java and operations extending to the islands of Lombok and Sumbawa (Krisnayanti et al. 2012; Male et al. 2013; Tomiyasu et al. 2016). In the ASGM, gold is recovered by miners through a two-stage process of whole-ore amalgamation and cyanidation. The primer mercury concentration of the amalgamation tailings is about $3000 \mathrm{mg} \mathrm{kg}(-1)$ and greater than $1600 \mathrm{mg} \mathrm{kg}(-1)$ for cyanidation tailings (Krisnayanti et al. 2012). Several studies have been conducted focusing on the distribution of heavy metals near-final disposal areas have already been conducted (Tomiyasu et al. 2019). It is a challenge for researchers to provide problem-solving technology for treating mercury-contaminated areas. Bioremediation includes technologies that accelerate natural processes for degrading or reducing toxic effects of harmful chemicals and thus provide a good cleaning strategy, especially in Indonesia.

The use of microorganisms has provided a safer and more economical alternative to conventional physicochemical practices. Metabolic processes of organisms mostly use contaminants as energy sources resulting in nontoxic or less toxic by-products (Winardi et al. 2019) Maziyah (2011) has been successful in obtaining four isolates of the genus Streptomyces spp. from the rhizosphere of the turfgrass (Cyperus rotundus L.) in mercury-contaminated areas in the traditional gold processing area of Selodong Hamlet, Buwun Mas Village, West Lombok, Indonesia. They are Streptomyces spp. AS1, Streptomyces spp. AS2, Streptomyces spp. AS6, and Streptomyces spp. BR28 with the best mercury resistance capability is at a concentration of $1 \mathrm{mM}$ (Streptomyces spp. AS6 and Streptomyces spp. BR28) and a concentration of $2 \mathrm{mM}$ (Streptomyces spp. AS1 and Streptomyces spp. AS2). The ability of mercury resistance in these isolates due to the ability of these isolates to bind mercury to the cytoplasm, membranes, and cell walls.

However, mercury reductase activity of four Streptomyces spp. in the process of detoxification of mercury into non-toxic or less toxic forms is not yet known, so further research is needed. This research is aimed to purify and determine the activity of mercuric reductase enzyme from Streptomyces spp. which can be used in future for mercury bioremediation in Indonesia.

\section{MATERIALS AND METHODS}

\section{Isolation and cultivation of Streptomyces spp.}

Four isolates belonging to the genus Streptomyces (strains AS1, AS2, AS6, and BR28) were isolated from the
Cyperus rotundus L. plant-soil samples in the traditional gold processing area of Selodong Hamlet, West Lombok (Maziyah 2011). Each isolate was taken as much as $0.1 \mathrm{~mL}$ from glycerol stock and inoculated in $5 \mathrm{~mL}$ medium Yeast Malt Extract (YM) broth. Incubation was carried out for three days at room temperature. Then as much as $0.1 \mathrm{~mL}$ of culture were inoculated into the SNA medium by the spread plate method and incubated at room temperature. Observations were carried out for four days to three weeks until the colonies grew, then streaked and stored in a sloping SNA medium as stock.

\section{Induction of mercury reductase}

The induction method of mercury reductase isolates belonging to the genus Streptomyces was modified from Amroso et al. (1998) and Maziyah (2011). One inoculating loop isolate from the SNA skew medium was grown in 5 $\mathrm{mL}$ YM broth medium and incubated for three days at room temperature. Then $10 \%(\mathrm{v} / \mathrm{v})$ of the liquid culture isolate was grown in $20 \mathrm{~mL}$ of $\mathrm{YM}$ broth liquid medium containing $0.05 \mathrm{mM} \mathrm{HgCl}_{2}$. The culture was then incubated at $30{ }^{\circ} \mathrm{C}$ at $125 \mathrm{rpm}$ incubator shaker for 5 days.

\section{Cell-free extract preparation}

Cell-free extract preparation was adapted from Ghos et al. (1998). The liquid culture was centrifuged at $1646 \mathrm{~g}$ for 30 minutes, then washed twice with $50 \mathrm{mM}$ buffer sodium phosphate $\mathrm{pH} 7.5$ containing $0.5 \mathrm{mM}$ EDTA and $14 \mathrm{mM} \beta$ mercaptoethanol. The obtained pellets were broken down using sea sand and centrifuged $1646 \mathrm{~g}$ at $4{ }^{\circ} \mathrm{C}$ for 30 minutes. The supernatant obtained was called cell-free extract of crude enzyme.

\section{Determination of mercury reductase activity}

Mercury reductase activity was measured by oxidation of $\mathrm{NADPH}_{2}$ at $\lambda 340 \mathrm{~nm}$. The method of measuring mercury reductase activity was performed according to the Ogunseitan (1998) and Zeroual et al. (2003) by adding 0.5 $\mathrm{mL}$ of enzyme extract to $3 \mathrm{~mL}$ of Mercury Reductase Assay (MRA) solution containing $50 \mathrm{mM}$ sodium phosphate buffer solution ( $\mathrm{pH} 7.5$ ), $100 \mu \mathrm{M} \mathrm{NADPH}_{2}, 0.2$ $\mathrm{mM} \mathrm{MgCl}_{2}, \quad 0,5 \mathrm{mM}$ EDTA, $0.1 \%$ (vol/vol) $\beta$ mercaptoethanol, and $200 \mu \mathrm{M} \mathrm{HgCl}_{2}$. Incubation was carried out for 60 minutes at $37^{\circ} \mathrm{C}$ in dark. Measurements by spectrophotometer at $\lambda 340 \mathrm{~nm}$ were carried out when the enzyme was added and after incubation 60 minutes to determine the initial $\mathrm{NADPH}_{2}$ concentration and the final $\mathrm{NADPH}_{2}$ concentration so that the amount of oxidized $\mathrm{NADPH}_{2}$ can be determined. The $\mathrm{NADPH}_{2}$ level was determined by the equation of the regression line $y=a x+b$ obtained from the standard $\mathrm{NADPH}_{2}$ curve. One unit of activity was defined as the amount of oxidized $\mathrm{NADPH}_{2}$ per $\mathrm{mg}$ of protein per minute $\left(\mu \mathrm{M} \quad \mathrm{NADPH}_{2} / \mathrm{mg}\right.$ protein/minute).

\section{Determination of protein concentration (Bradford Assay)}

The determination of protein concentration was carried out under the Coomassie Blue (Bradford Assay) method (Bradford 1976). $60 \mu \mathrm{L}$ crude enzymes were added with 3 $\mathrm{mL}$ of reagent and incubated for 2 minutes at room 
temperature. Furthermore, absorbance was measured at $\lambda$ $595 \mathrm{~nm}$. Protein concentration $(\mathrm{mg} / \mathrm{mL})$ was calculated from the equation of the standard curve for protein curves.

\section{Enzyme purification}

Streptomyces spp. Mercuric reductase purification was carried out through several stages, starting from deposition with ammonium sulfate, dialysis, and column chromatography (DEAE Sepharose anion column chromatography). At each purification stage, specific enzyme activity and protein concentration were measured.

\section{Characterization of mercury reductase Effect of $p H$}

The effect of $\mathrm{pH}$ on mercury reductase was carried out to determine the optimum $\mathrm{pH}$ of mercury reductase. Measurement of the effect of $\mathrm{pH}$ on the activity of mercury reductase was based on the method of Zeroual et al. (2003) with modification that measures the activity of mercury reductase at various $\mathrm{pH}$ variations, namely $\mathrm{pH} 4$ and 5 (Sodium acetate), 6 and 7.5 (Sodium phosphate), 8 and 9 (Buffer Tris-HCl) with 10-minute of incubation time.

\section{Effect of temperature}

Measurement of the effect of temperature on the activity of mercury reductase is carried out to determine the optimum temperature of mercury reductase. Measurements were made by measuring the enzyme activity at various temperature variations $\left(20^{\circ} \mathrm{C}, 30^{\circ} \mathrm{C}, 40^{\circ} \mathrm{C}, 50^{\circ} \mathrm{C}, 60^{\circ} \mathrm{C}\right.$, $70^{\circ} \mathrm{C}, 80^{\circ} \mathrm{C}$, and $90^{\circ} \mathrm{C}$ ) in the optimum $\mathrm{pH}$ solution from previous measurements and incubated for 10 minutes.

\section{Measurement of enzyme molecular weight}

Crude protein enzymes, the results of the deposition of ammonium sulfate, dialysis, and columns were analyzed by SDS PAGE.

\section{Data analysis}

Protein concentration was calculated from the equation of the regression line $y=a x+b$ obtained from the standard curve of protein. Data on mercury reductase activity was calculated by measuring the levels of oxidized $\mathrm{NADPH}_{2}$ per $\mathrm{mg}$ of protein per minute $\left(\mu \mathrm{M} \quad \mathrm{NADPH}_{2} / \mathrm{mg}\right.$ protein/minute) obtained from the regression line equation of $y=a x+b$ for the standard $\mathrm{NADPH}_{2}$ curve.

\section{RESULTS AND DISCUSSION}

\section{Mercury resistance and mercury reductase activity of Streptomyces spp.}

Results exhibited that Streptomyces spp. AS1, Streptomyces spp. AS2, and Streptomyces spp. AS6 showed decreased resistance to $\mathrm{HgCl}_{2}$ at $1 \mathrm{mM}$ concentration. The growth inhibition diameters of the three isolates were $10.3 \mathrm{~mm}, 9.6 \mathrm{~mm}$, and $20 \mathrm{~mm}$ (Figure 1). The results of previous studies (Maziyah 2011) mention Streptomyces spp. AS1, Streptomyces spp. AS2, and Streptomyces spp. AS6 is resistant to $\mathrm{HgCl}_{2}$ at a concentration of $1 \mathrm{mM}$ with a diameter of growth inhibition successively $6.53 \mathrm{~mm}, 7.47 \mathrm{~mm}, 8.77 \mathrm{~mm}$. The resilience of Streptomyces spp. BR 28 has decreased slightly, from $9.23 \mathrm{~mm}$ to $9.3 \mathrm{~mm}$. So it can be concluded that the resistance ability of Streptomyces spp. BR 28 against $\mathrm{HgCl}_{2}$ remains the same.

Measurement of the specific activity of mercury reductase on four isolates showed that Streptomyces spp. BR28 has the highest specific activity of $56.94 \mathrm{U} / \mathrm{mg}$ compared to Streptomyces spp. AS1 $17.49 \mathrm{U} / \mathrm{mg}$, Streptomyces spp. AS2 $15.43 \mathrm{U} / \mathrm{mg}$, and Streptomyces spp. AS6 $30.66 \mathrm{U} / \mathrm{mg}$ (Figure 2).

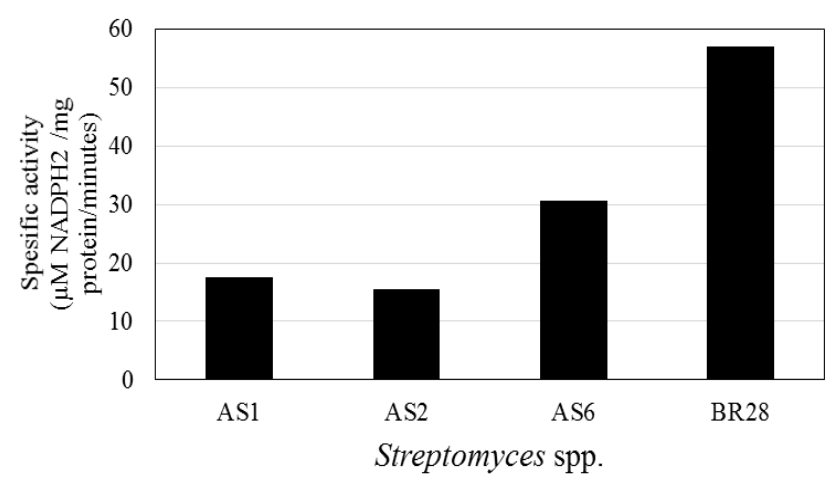

Figure 2. The specific activity of mercury reductase on four isolates of Streptomyces spp.

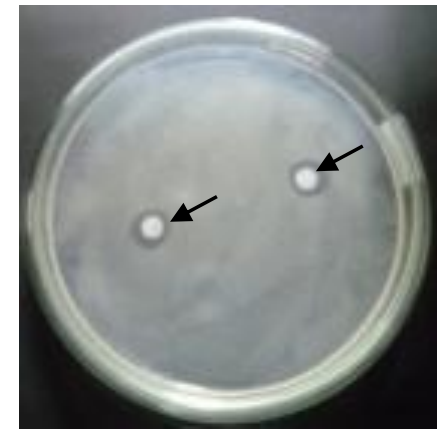

A

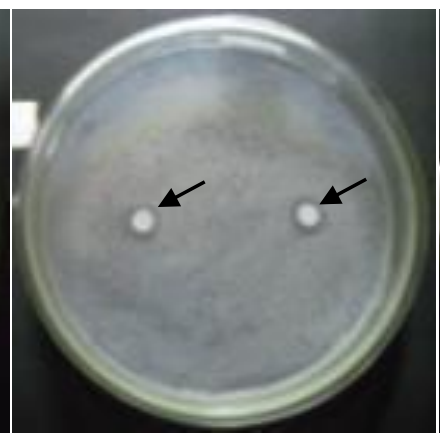

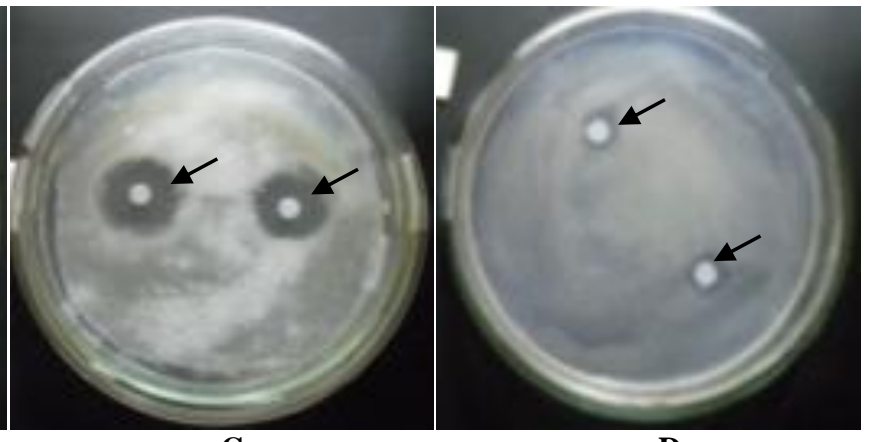

B

C

D

Figure 1. Mercury resistance activity of Streptomyces spp. A. Streptomyces spp. AS1 with clear zone 10.3 mm; B. Streptomyces spp. AS2 with clear zone $9.6 \mathrm{~mm}$; C. Streptomyces spp. AS6 with clear zone $20 \mathrm{~mm}$; D. Streptomyces spp. BR28 with clear zone $9.3 \mathrm{~mm}$ 
Mercuric reductase is an enzyme located in the cytoplasm (Furukawa and Tonomura 1972; Schottel 1978; Fox and Walsh 1982; Meissner 1983; Robinson and Tuovinen 1984; Summers 1986) and is inducible (Weiss et al. 1977; Robinson and Tuovinen 1984; Nakahara et al. 1985; Summers 1986; Bogdanova et al. 1988; Petrus et al. 2015) so that mercury reductase will only be produced by organisms as a response if there are mercury compounds in the growth environment (Robinson and Tuovinen 1984). Nakahara et al. (1985) explain that there is a correlation between mercury resistance and the synthesis of mercury reductase. The ability to produce enzymes will be lost if the organism is grown in a medium that does not contain mercury compounds it eventually will lose its resistance to mercury (Olson et al. 1982; Robinson and Tuovinen 1984; Nakahara et al. 1985). So it can be concluded, the members of the genus Streptomyces showed a reduced ability of mercury resistance because the isolates were stored for a long time in a medium that does not contain mercury. The mechanism of transformation and mercury resistance starts from the binding process of $\mathrm{Hg}^{2+}$ (Nies 2009) that occurs in the periplasm (for gram-negative bacteria) and periplasmic binding protein (merP) (for gram-positive bacteria) (Nies 2009; Silver and Hobman 2007; Silver and Phung 2005). merP will bring $\mathrm{Hg}^{2+}$ to mer $\mathrm{T}$, then $\mathrm{Hg}^{2+}$ will be released by merP quickly through 2 of the 4 cysteines found in merT (Silver and Phung 2005). merT functions to transfer $\mathrm{Hg}^{2+}$ from merP to mercury reductase (merA) and $\mathrm{Hg}^{2+}$ will be reduced to $\mathrm{Hg}^{0}$ (Hughes and Poole 1989; Gadd 1990; Hobman and Brown 1997; Silver and Phung 2005; Silver and Hobman 2007).

Silver and Hobman (2007) describe the reduction process of $\mathrm{Hg}^{2+}+$ to $\mathrm{Hg}^{0}$ starting with the binding of $\mathrm{Hg}^{2+}$ to the mercury reductase subunit of the carboxyl-terminal part of Cys 557-Cys 558. Then it is moved quickly through the thiol-thiol exchange to the Cys 135-Cys 140 monomer pair. Then $\mathrm{Hg}^{2+}$ will be on the active site of the Cys 135 Cys 140 pair and reduced to $\mathrm{Hg}^{0}$ by electron transport from the FAD cofactor. Eventually, the volatile $\mathrm{Hg}^{0}$ will be removed from the microorganism cell.

\section{Enzyme purification}

The results indicate an increase in specific activities at each stage of purification. The specific activity of ammonium sulphate precipitation was $1703.477 \mathrm{U} / \mathrm{mg}$ protein. The specific activity of cell-free enzyme extracts increased the activity 33.56 times (Table 1 ).

The specific activity of mercury reductase resulting from dialysis has increased. This is indicated by an increase in the specific activity value of 50.23 times the specific activity of the free cell extract. The highest specific activity was found by column chromatography fraction which was 431.87 times cell-free extract. Enzyme-specific activity was higher in line with the increasing stages of purification. The specific activity of column chromatography fraction was higher than dialysis fraction, ammonium sulfate precipitation, and cell-free enzyme extract. So it can be said that the enzymes resulting from column chromatography fractions are purer compared to cell-free enzyme extracts.

\section{Mercury reductase activity at various pH}

Testing the effect of $\mathrm{pH}$ on the activity of mercury reductase revealed that the enzyme activity was lowest at $\mathrm{pH} 4$ and optimum at pH 7.5, then decreased (Figure 3). Increasing or decreasing the optimum $\mathrm{pH}$ will change the ionization group on the active site of the enzyme and the substrate which will further slow-down or prevent the formation of the enzyme-substrate complex (Byrne 2013; Giovanella et al. 2015). According to Copeland (2000), enzymes have tertiary structures that are sensitive to $\mathrm{pH}$ and will generally be denatured at $\mathrm{pH}$ values that are too low or too high.

Streptomyces spp. BR 28 has an optimal $\mathrm{pH}$ of 7.5 with an activity value of $47.5 \mathrm{U}$. This is in line with Copeland (2000) which states that most enzymes work optimally at neutral $\mathrm{pH}$. This statement was confirmed by Bafana et al. (2017), Zeroual et al. (2003), Olson et al. (1982), Nakahara et al. (1985) which states that the optimum mercury reductase at $\mathrm{pH}$ approaches neutral $\mathrm{pH}$.

\section{Mercury reductase activity at various temperature}

Mercury reductase showed the lowest activity at $20{ }^{\circ} \mathrm{C}$ and optimum at $80{ }^{\circ} \mathrm{C}$ and then decreased. An increase in temperature will cause an increase in the kinetic speed of the enzyme and will effectively increase the amount of fusion between the substrate and the enzyme so that the substrate-enzyme complex is formed (Byrne 2013). Each enzyme has an optimum temperature (Byrne 2013).

Table 1. Purification of mercury reductase Streptomyces spp. BR28

\begin{tabular}{|c|c|c|c|c|c|c|c|c|}
\hline \multirow[b]{2}{*}{ Stage } & \multirow[b]{2}{*}{$\begin{array}{c}\text { Volume } \\
\text { (mL) }\end{array}$} & \multicolumn{2}{|c|}{ Protein } & \multicolumn{3}{|c|}{ Enzyme Activity } & \multicolumn{2}{|c|}{ Purification } \\
\hline & & $\begin{array}{c}\text { Protein } \\
\text { concentrati } \\
\text { on }(\mathrm{mg} / \mathrm{mL})\end{array}$ & $\begin{array}{c}\text { Total of } \\
\text { protein } \\
(\mathbf{m g})\end{array}$ & $\begin{array}{c}\text { Enzyme } \\
\text { activity } \\
\text { (Unit) }\end{array}$ & $\begin{array}{c}\text { Specific } \\
\text { activity } \\
\text { (Unit/mg of } \\
\text { protein) }\end{array}$ & $\begin{array}{l}\text { Total of } \\
\text { activity } \\
\text { (Unit) }\end{array}$ & $\begin{array}{l}\text { Purification } \\
\text { factor }\end{array}$ & $\begin{array}{l}\text { Yield } \\
(\%)\end{array}$ \\
\hline Cell-free extract & 100 & 0.051 & 5.1 & 0.854 & 50.753 & 258.840 & 1 & 100 \\
\hline Ammoniumsulphate precipitation & 4 & 0.399 & 1.596 & 13.590 & 1703.477 & 2718.749 & 33.56 & 1050.36 \\
\hline Dialysis & 4 & 0.238 & 0.952 & 12.140 & 2549.457 & 2427.083 & 50.23 & 937.68 \\
\hline Column chromatography & 1 & 0.001 & 0.001 & 1.25 & 21918.95 & 21.919 & 431.87 & 8.47 \\
\hline
\end{tabular}


The test results (Figure 4) showed that activity of mercury reductase Streptomyces spp. BR 28 was optimum at a $80{ }^{\circ} \mathrm{C}$ temperature of which was $199.16 \mathrm{U}$, four times higher than at a temperature of $50{ }^{\circ} \mathrm{C}$. So it can be concluded that the mercuric reductase from Streptomyces was a thermophilic enzyme. Several previous studies have shown that mercuric reductase is an enzyme that is resistant to high temperatures. Including research, Sayed et al. (2014) explained that the novel mercuric reductase from the unique deep brine environment of Atlantis II in the Red sea is stable at high temperatures. Maged et al. (2019) also found that mercuric reductase from the red sea has thermal tolerance at $70{ }^{\circ} \mathrm{C}$. Which was followed by Freedman et al. (2012) research, chemotrophic thermophilic Aquificae possed thermophilic mercuric reductase.

\section{The molecular weight of mercury reductase}

The molecular weight of mercury reductase Streptomyces spp. BR28 has been checked by Sodium Dodecyl Sulphate Polyacrylamide Gel Electrophoresis (SDS PAGE) technique. Protein bands were parallel to the markers ranging from $50 \mathrm{kDa}$ to $75 \mathrm{kDa}$ (Figure 5).

The molecular size of mercury reductase of several gram-positive and gram-negative bacteria that has been identified was ranged from $56 \mathrm{kDa}$ and $62 \mathrm{kDa}$ in Pseudomonas aeruginosa PAO 9501 (Fox and Walsh 1981), $60 \mathrm{kDa}$ in Lysinibacillus sphaericus strain G1 (Bafana et al. 2017), $69 \mathrm{kDa}$ in Bacillus sp (Moore et al. 1989), $54 \mathrm{kDa}$ and $69 \mathrm{kDa}$ in Azotobacter chroococcum (Gosh et al. 1998), $64 \mathrm{kDa}$ and $55.5 \mathrm{kDa}$ in Escherichia coli J531 (R831) (Schottel 1977), and $62 \mathrm{kDa}$ in Klebsiella pneumoniae (Zeroual et al. 2003). Thus, it can be estimated the molecular weight of mercury reductase Streptomyces spp. BR28 ranged from $50 \mathrm{kDa}$ to $75 \mathrm{kDa}$. The exact molecular weight of mercury reductase was not known with certainty because the SDS PAGE fraction of column chromatography that has the highest activity did not show the presence of a single protein band to ensure the molecular weight of mercury reductase (Figure 5).

The results of the SDS page column chromatography showed three-column fractions that showed protein bands (fractions four, five, and six). Fraction four showed seven protein bands, fraction five has six protein bands, and fraction six has two protein bands (Figure 6).

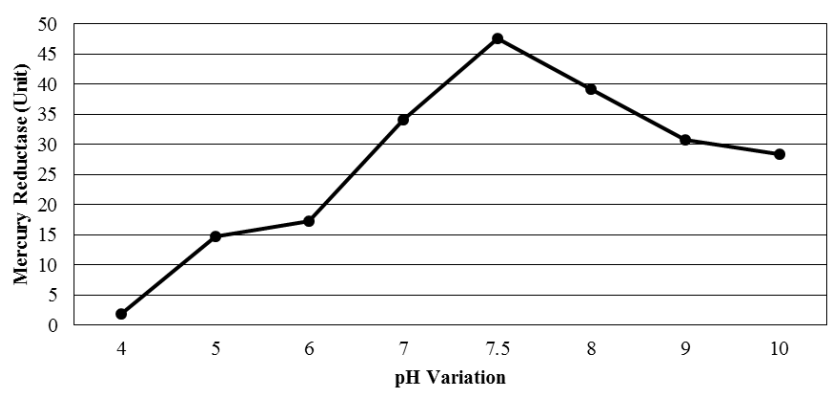

Figure 3. The activity of crude enzyme from Streptomyces spp. BR28 at various $\mathrm{pH}$ values
A large number of protein bands were visible in fractions four, five, and six suggest that the enzymes obtained from the DEAE sepharose anion column chromatography were not yet pure. Thus, purification using DEAE sepharose anion column chromatography was not able to separate mercury reductase from other proteins. Mercuric reductase is a central enzyme in the organomercurial resistance system elaborated by many soils and enteric bacteria (Fox and Walsh 1981).

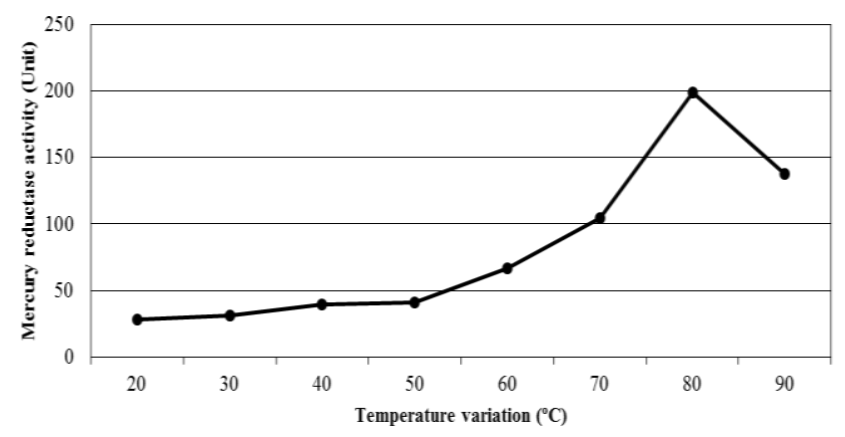

Figure 4. The activity of crude enzyme Streptomyces spp. BR28 at various temperatures
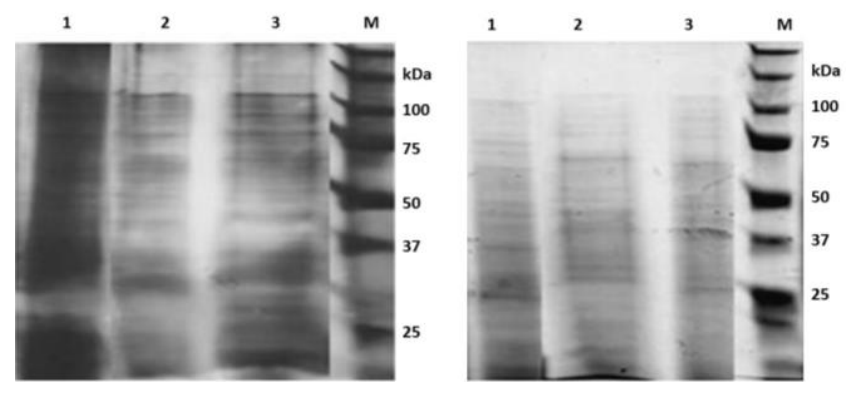

Figure 5. SDS PAGE results of mercury reductase Streptomyces spp. BR28 with (A) silver staining; (M) protein marker; (Lane 1) crude enzyme; (Lane 2) result of dialysis; (Lane 3) ammonium sulfate precipitation yield 30-60\%; (B) coomassie blue coloring; (M) protein marker; (Lane 1) crude enzyme; (Lane 2) result of dialysis ; (Lane 3) ammonium sulfate precipitation yield 30-60\%

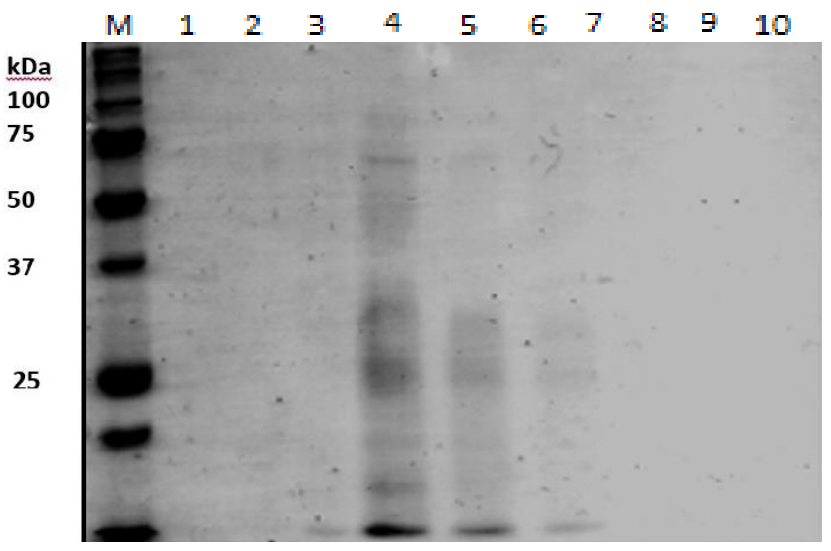

Figure 6. SDS PAGE results of mercury reductase column chromatography Streptomyces spp. BR 28, (M) Protein marker, (Lane 1-10) Fraction 1-10 
Mercury resistant bacteria (MRB) consists of a broad spectrum of gram-positive and gram-negative bacteria that have a peculiar mechanism of countering and eventually converting $\mathrm{Hg}$ from highly toxic form to non-toxic form using that enzyme. Previous studies have never measured mercuric reductase activity specifically on Streptomyces spp. isolated from the Cyperus rotundus rhizosphere in mercury-contaminated areas. Therefore, in this study, several methods were applied to measure the optimum conditions for mercury reductase activity from Streptomyces spp. that has never been done before in Indonesia.

From the result, it is known that the total activity of the cell-free extract mercuric reductase Streptomyces spp. was 258.840 units of the complete protein $5.1 \mathrm{mg}$. This enzyme activity is greater than the enzyme activity in Azotobacter chroococcum, which is only 25.187 units of $201.5 \mathrm{mg}$ of total protein (Ghosh et al. 1999). Other studies have also shown that the specific activity of the mercuric reductase Streptomyces spp. is superior with a value of 50,753 units/mg of protein compared to mercuric reductase of Klebsiella pneumoniae with a value of 49.24 units/mg of protein (Zeroual et al. 2003). Recently, mercuric reductase activity has also been measured from Lysinibacilus sphaericus with a value of 2.4 and 0.13 units/mg (Bafana et al. 2013). These findings in this study provided information that mercuric reductase from Streptomyces spp. has promising capabilities for the bioremediation process against mercury contamination.

In this study, it can be concluded that Streptomyces spp. BR28 can be considered as a mercury bioremediation agent because it has mercury reductase with a specific activity of $21918.95 \mathrm{U} / \mathrm{mg}$ protein with a purity level of 431.87 times cell-free extract. The optimum $\mathrm{pH}$ and temperature of the mercury reductase isolates were 7.5 and $80{ }^{\circ} \mathrm{C}$, respectively. The isolate also has mercury reductase with sizes ranging from $50 \mathrm{kDa}$ to $75 \mathrm{kDa}$. So, this study provided important results and gave new insight for next research, especially in the bioremediation field.

\section{ACKNOWLEDGEMENTS}

This research is partly funded by BOPTN Research Grant of the Faculty of Biology, Universitas Gadjah Mada (UGM), Yogyakarta, Indonesia in 2013 to YAP (Contract no. UGM/BI/2408/M/05/01).

\section{REFERENCES}

Amroso MJ, Castro GR, Carlino FJ, Romero NC, Hill RT, Oliver G. 1998 Screening of heavy metal-tolerant actinomycetes isolated from the Sali River. J Gen Appl Microbiol 44: 129-132. DOI: 10.2323/jgam.44.129.

Bafana A, Khan F, Suguna K. 2017. Structural and functional characterization of mercuric reductase from Lysinibacillus sphaericus strain G1. Biometals 30 (5): 809-819. DOI: 10.1007/s10534-0170050-x.

Bogdanova ES, Mindlin SZ, Kalyaeva ES, Nikiforov VG. 1988. The diversity of mercury reductase among mercury-resistant bacteria. FEBS Lett 234: 280-282. DOI: 10.1016/0014-5793(88)80098-X.
Bradford MM. 1976. A rapid and sensitive method for quantitation of microgram quantities of protein utilizing the principle of protein-dye binding. Anal Biochem 72: 248-254 DOI: 10.1006/abio.1976.9999.

Dash HR, Das S, 2012. Bioremediation of mercury and the importance of bacterial mer genes. Intl Biodeterior Biodegrad 75: 207-213. DOI: 10.1016/j.ibiod.2012.07.023

Fatimawali, Kepel BJ, Gani MA, Tallei TE. 2020. Comparison of bacterial community structure and diversity in traditional gold mining waste disposal site and rice field by using a metabarcoding approach. Intl J Microbiol 2020: 1858732. DOI: 10.1155/2020/1858732.

Fox B, Walsh CT. 1982. Mercuric reductase, purification, and characterization of a transposon-encoded flavoprotein containing an oxidation-reduction active disulfide. J Biol Chem 257: 2498-2503. DOI: 10.1016/S0021-9258(18)34951-2

Freedman Z, Zhu C, Barkay T. 2012. Mercury resistance and mercuric reductase activities and expression among chemotrophic thermophilic Aquaificae. Appl Environ Microbiol 78 (18): 6568-6575. DOI: 10.1128/AEM.01060-12

Furukawa K. Tonomura K. 1971. Metallic mercury-releasing enzyme in mercuri-resistant Pseudomonas. Agr Biol Chm 36: 217-226 DOI: 10.1080/00021369.1972.10860232

Gadd GM. 1990. Metal Tolerance in Microbiology of Extreme Environments. Open University Press, Millon Keynes.

Giovanella P, Cabral 1, Bento F, Gianello C, Camargo FAO. 2015. Mercury (II) removal by resistant bacterial isolate and mercuric (ii) reductase activity in a new strain of Pseudomonas sp B50A. N Biotechnol 33 (1): 216-23 DOI: 10.1016/j.nbt.2015.05.006

Glumoff T. 2004. Physiology and Maintenance, on the Determination of Enzyme Structure, Function, and Mechanism. Encyclopedia of Life Support Systems (EOLSS), UNESCO, Geneva.

Gopinath E, Kaaret TW, Bruice TC. 1989. Mechanism of mercury (II) reductase and influence of ligation on the reduction of mercury (II) by water soluble 1,5-dihydroflavin. Proc Natl Acad Sci USA 86: 30413044. DOI: 10.1073/pnas.86.9.3041.

Gosh S, Sadhukhan PC, Chaudhuri J, Gosh DK, Mandal A. 1998. Purification and properties of mercuric reductase from Azotobacter chroococcum. J Appl Microbiol 86: 7-12. DOI: 10.1046/j.13652672.1999.00605.x

Hobman JL, Brown NL. 2007. Bacterial mercury-resistance genes in metal ions. In: Biological System, Mercury, and its effects on Environment and Biology 34. Marcel Dekker Inc, USA.

Imron MF, Kurniawan SB, Soegianto A. 2019. Characterization of mercury-reducing potential bacteria isolated from Keputih non-active sanitary landfill leachate, Surabaya, Indonesia under different saline conditions. J Environ Manag 241: 113-122 DOI: 10.1016/j.jenvman.2019.04.017

Irawati W, Patricia, Soraya, Y., Baskoro, A.H. 2012. A study on mercuryresistant bacteria isolated from a gold mine in Pongkor Village, Bogor, Indonesia. Hayati J Biosci 19 (4): 197-200. DOI: 10.4308/hjb.19.4.197

Krisnayanti BD, Anderson CWN, Utomo WH, ad Xinbin Feng X, Handayanto E, Mudarisna N, Ikram H, Khususiah. 2012. Assessment of environmental mercury discharge at a four-year-old artisanal gold mining area on Lombok Island, Indonesia. J Environ 14: 2598. DOI: $10.1039 / \mathrm{c} 2 \mathrm{em} 30515 \mathrm{a}$

Kumari S, Amit, Jamwal R, Mishra N, Singh DK. 2020. Recent development in environmental mercury bioremediation and its toxicity: a review. Environ Nanotechnol Monit Manag 13: 100283 DOI: $10.1016 /$ j.enmm.2020.100283

Maged M, Hosseiny AE, Saadeldin MK, Aziz RK, Ramadan E. 2019. Thermal stability of a mercuric reductase from the Red Sea Atlantis II hot brine environment as analyzed by site-directed mutagenesis. Appl Environ Microbiol 85 (3): e02387-18. DOI: 10.1128/AEM.02387-18.

Mahbub KR, Bahar MM, Labbate M, Krishnan K, Andrews S, Naidu R, Megharaj M. 2017. Bioremediation of mercury: not properly exploited in contaminated soils. Appl Microbiol Biotechnol 101 (3): 963-976. DOI: 10.1007/s00253-016-8079-2.

Male YT, Reichelt-Brushett AJ, Matt Pocock M, Nanlohy A. 2013. Recent mercury contamination from artisanal gold mining on Buru Island, Indonesia - Potential future risks to environmental health and food safety. Mar Poll Bull 77: 428-433. DOI: 10.1016/j.marpolbul.2013.09.011.

Maziyah, S. 2011. Keanekaragaman dan Potensi Streptomycetes Rizosper Rumput Teki (Cyperus rotundus L.) Daerah Tercemar Merkuri sebagai Agen Bioremediasi Cemaran Logam. [Thesis]. Fakultas Biologi, Universitas Gadjah Mada, Yogyakarta. [Indonesian] 
Meissner PS, Falkinham III JO. 1983. Plasmid-Encoded Mercuric Reductase in Mycobacterium scrofulaceum. J Bacteriol 157 (2): 669 672.

Moore M, Distefano MD, Walsh CT, Schiering N, Pai EF. 1989. Purification, crystallization, and preliminary X-ray diffraction studies of flavoenzyme mercuric ion reductase from Bacillus sp. strain RC607. J Biol Chem 264: 14386-14388. DOI: 10.1016/S00219258(18)71690-6.

Nakahara H, Schottel JL, Yamada T, Miyakawa Y, Asakawa M, Harville J, Silver S. 1985. Mercuric reductase enzymes from Streptomyces species and group B Streptococcus. J Gen Appl Microbiol 131: 10531059. DOI: 10.1099/00221287-131-5-1053

Nies DH.1999. Microbial heavy-metal resistance. Appl Microbiol Biotechnol 51: 730-750. DOI: 10.1007/s002530051457

Ogunseitan OA. 1998. Protein method for investigating mercuric reductase gene expression in aquatic environment. Appl Environ Microbiol 64 (2): 695-202. DOI: 10.1128/AEM.64.2.695-702.1998.

Olson GJ, Porter FD, Rubinstein J, Silver S. 1982. Mercuric reductase enzyme from a mercury-volatilizing strain of Thiobacillus ferroxidans. J Bacteriol 151: 1230-1236. DOI 10.1128/JB.151.3.1230-1236.1982.

Petrus AK, Rutner C, Liu S, Wang Y, Wiatrowski HA. 2015. Mercury reduction and methyl mercury degradation by the soil bacterium Xanthobacter autotrophicus Py2. Appl Environ Microbiol 81 (22): 7833-7838 DOI: 10.1128/AEM.01982-15.

Popa C, Bahrim G. 2011. Streptomyces Tyrosinase: Production and Practical Application. Innov Roman Food Biotechnol 8: 1-7.

Purkan P, Nuzulla YF, Hadi S, Prasetyawati ET. 2017. Biochemical properties of mercuric reductase from local isolate of bacillus $s p$ for bioremediation agent. Molekul 12 (2): 182-188. DOI 10.20884/1.jm.2017.12.2.398

Rintala H. 2003. Streptomycetes in Indoor Environments PCR based Detection and Diversity. [Dissertation]. Kuopio University, Finland.

Robinson JB, Tuovinen OH. 1984. Mechanism of microbial resistance and detoxification of mercury and organomercury compounds: physiological, biochemical, and genetic analyses. Microbiol Rev 48 (2): 95-124.
Sayed A, Ghazy MA, Ferreira AJS, Setubal JC, Chambergo FS, Ouf A, Adel M, Dawe AS, Archer JAC, Bajic VB, Siam R, El-Dorry H. 2014. A novel mercuric reductase from The Unique Deep Brine Environment of Atlantis II in The Red Sea. J Biol Chem 289(3): 1675-1687 DOI: 10.1074/jbc.M113.493429.

Schottel, Janet L. 1977. The mercuric and organomercurial detoxifying enzymes from a plasmid-bearing strain of Escherichia coli. J Biol Chem 253: 12. DOI: 10.1016/S0021-9258(17)34725-7.

Silver S, Hobman JL. 2007. Mercury microbiology: resistance systems, environmental aspects, methylation, and human health. Microbiol Monogr 6: 357-370. DOI: 10.1007/7171_2006_085.

Silver S, Phung LT. 2005. A bacterial view of the periodic table: genes and proteins for toxic inorganic ions. J Ind Microbiol Biotechnol 32: 587-605. DOI: 10.1007/s10295-005-0019-6.

Summers AO. 1986. Organization, expression, and evolution of genes for mercury resistance. Ann Rev Microbiol 40: 607-34. DOI: 10.1146/annurev.mi.40.100186.003135.

Tomiyasu T, Kodamatani H, Hamada YK., Matsuyama A, Imura R, Taniguchi Y, Hidayati N, Rahajoe JS. 2016. Distribution of total mercury and methyl mercury around the small-scale gold mining area along the Cikaniki River, Bogor, Indonesia. Environ Sci Pollut Res. 24: 2643-2652 DOI: 10.1007/s11356-016-7998-x.

Undabarrena A, Ugalde JA, Seeger M, Camara B. 2017. Genomic data mining of the marine actinobacteria Streptomyces sp. H-KF8 unveils insights into multi-stress related genes and metabolic pathways involved in antimicrobial synthesis. Peer $\mathrm{J}$ 2: 35 . DOI: 10.7717/peerj.2912.

Weiss AA, Murphy SD, Silver S. 1977. Mercury and organomercurial resistance determined by plasmids in Staphylococcus aureus. J Bacteriol 132: 197-208. DOI: 10.1128/JB.132.1.197-208.1977.

Winardi, Sudrajat, Haryono E, Soetarto ES. 2019. Potential of soil bacteria as mercury bioremediation agent in traditional gold mining. Biosaintifika J Biol Biol Educat 11 (1): 108-116 DOI: 10.15294/biosaintifika.v11i1.16688.

Zeroual Y, Moutaouakkil A, Dzairi FZ, Talbi M, Chung PU, Lee K, Blaghen M. 2003. Purification and characterization of cytosolic mercuric reductase from Klebsiella pneumoniae. Ann Microbiol 5 3(2): 149-160. 